\title{
A Misunderstood Friendship: Mao Zedong, Kim Il- sung, and Sino-North Korean Relations, 1949-1976. By Zhihua Shen·Yafeng Xia. New York: Columbia University Press, 2018. xiv, 357 pp [ISBN 9780231188265]
}

Tomer Nisimov

A superficial examination of the history of the Sino-North Korean relations would have suggested that the two countries have a unique connection with each other, a fraternal-like relationship, and perhaps an unbreakable alliance. Ostensibly, the People's Republic of China (PRC) and the Democratic People's Republic of Korea (DPRK, or simply known as North Korea) seem to share many features: both countries rose up after the conclusion of WWII and after long decades of national and antiimperialist struggles, in both countries the state ideology is based on Marxism-Leninism, and both countries in practice are governed by a Leninist party, the Communist Party of China and the Korean Workers' Party. However, a closer investigation of the nature of the Sino-North Korean relations reveals a more complex picture. Shen Zhihua and Xia Yafeng's book addresses the complexity of Sino-North Korean relations and shat-

* Tomer Nisimov is a visiting scholar at Academia Sinica and National Chengchi University, Taiwan. He has obtained his Bachelor and Master degrees in Asian Studies from the Hebrew University of Jerusalem. His research focuses on transregional history and interethnic relations during China's Civil War, and twentiethcentury history of Northeast Asia. 
ters the myth about the unequivocally amicable relationship between the two countries.

A Misunderstood Friendship is a valuable addition to the field of modern East Asian history and to the history of international relations within the Communist camp in particular. It is the first book of its kind where Sino-North Korean relations stand at the center of its focus. As such, the book differs from many other studies of the inter-Communist relations that have largely focused on Sino-Soviet ties. Shen and Xia have taken upon themselves the challenging task of reexamining the history of SinoNorth Korean relations and they provide a highly original interpretation. The book's seven chapters cover the period of Mao's China (1949-1976), ending with an epilogue that concisely touches the period of reforms and opening-up of China under Deng Xiaoping. The authors incorporate sources in different languages, mainly Chinese, Russian and Korean, and of different types, including archival documents and interviews, which helps in providing new information about many events that are covered in the book. The authors elaborate the main point of the book in the introduction, where they present and disprove the myth about Sino-North Korean relations. Shen and Xia argue that in contrast to the official press and propaganda of China and North Korea, which have tended to praise their mutual relations, the two countries in fact maintain a very complex relationship, often accompanied by mistrust and disagreement. Much of this myth of good relations derives from the fact that the real nature of their relations remains concealed from the public or outside observers.

The first two chapters of the book detail the most pivotal years in SinoNorth Korean relations, when both sides were waging their wars of liberation and occupied with national unification, first China (1945/1946-1949), and then Korea (1950-1953). These years shaped much of the nature of the relationship and the understanding between the two countries' leaderships and have implications and resonance that extend far beyond this period. Chapter 1 covers the time during which North Korea was heavily influenced by the USSR, following its liberation from Japanese control by the Soviet Army in late 1945. It also includes the early relations between 
the Korean and Chinese Communists and their common revolutionary struggles, first against Japanese imperialism and later during China's Civil War. By utilizing archival materials in Taiwan - mainly the Guomindang's intelligence reports, some of which expose probably the earliest agreements between the Chinese Communists and North Korea and the latter's direct intervention in the Civil War ${ }^{1}$ - the authors could have considerably expanded the scope of Korean and, more importantly, North Korean assistance to the Chinese Communists during the Civil War. Without these crucial details, Chapter 2, which focuses on the period of the Korean War and the significant changes taking place in the two countries' positions toward each other, portrays Sino-North Korean relations in an unbalanced way, outlining China's aid to North Korea and intervention during the Korean War but downplaying North Korea's own role. The Guomindang's intelligence reports also mention that the plans to wage a war of unification on the Korean peninsula were made as early as October 1947 and were promoted by the Soviet authorities in North Korea and that members of the CPC Northeast Bureau were aware of these plans. These reports therefore undermine the authors' attempt to refute former observations of "collusion among the three countries" (p. 27).

The period of the Korean War saw the first strains and differences between the leaderships of China and North Korea. Here, in Chapter 2, the authors show the differences in strategies and other disagreements between the military and political leaders of the two countries regarding the way the war should be conducted. This was a crucial time for Sino-North Korean relations, and those strains eventually led to mistrust and suspicions that lasted beyond the Korean War. Such strains notwithstanding, China and North Korea officially supported each other and emphasized their comradeship. China's direct intervention in the Korean War, in contrast to the USSR's avoidance, heralded the end of the Soviet hegemonic

1 Tomer Nisimov, "The Role of North Korea in China's Civil War: The Soviet-Led North Korean Assistance to the CPC in the Northeast Theater, 1946-1948," Journal of Chinese Military History (forthcoming). 
stance in North Korea and the latter's shift to China.

In Chapter 3 the authors discuss the short period following the Korean War and emphasize the Chinese Communists' readiness to assist North Korea in order to maintain the alignment between the two countries. At the same time, Kim Ilsǒng was preoccupied with consolidating his and the guerillas' power domestically and warding off the external influences of both China and the USSR. The chapter ends with the August Incident of 1956, when an attempt to oust Kim Ilsǒng was averted and a joint Sino-Soviet delegation headed by Anastas Mikoyan and Peng Dehuai was sent to Pyŏnyang. According to the authors, the purpose of the delegation was to advise Kim Ilsǒng on how to fix the political issues and restore political order and stability (p. 102). Following this, they claim, North Korea sought to further distance itself from China and the USSR, and Mao was concerned that North Korea might separate from the socialist camp. China therefore refused to grant the North Korean government additional economic aid and relations between the two countries continued to deteriorate, with North Korea turning to its other benefactor, the USSR, for aid.

Chapters 4 and 5 deal with China's attempts to win over North Korea, while North Korea was trying to use the USSR as a balancing measure against excessive Chinese influence. If before 1957 China had maintained a more active and interventionist policy toward North Korea which led, in part, to North Korea's reliance on the USSR, by 1957 this policy had changed. The authors point out that by that time China had accumulated prestige as a leading power in the socialist camp, challenging Soviet authority, and therefore Mao sought to bring North Korea closer to China at the expense of the USSR. In order to do that, China's policy toward North Korea became more conciliatory: it consented to reinstate its economic aid and to withdraw the Chinese People's Volunteer Forces from North Korea, which was implemented by late 1958. This was a significant action for improving Sino-North Korean relations. While answering Kim Ilsǒng's desire to oust all foreign troops from the Korean peninsula, including the Chinese Volunteers in the North, it also served Mao's inten- 
tion to restore the trust between the two countries and perhaps to obscure China's image as an interventionist power.

Chapter 5 examines the escalation of the Sino-Soviet split and its implications for North Korea. Kim Ilsǒng took advantage of both powers' willingness to ameliorate their respective relations with North Korea and secured economic aid and other concessions from both. Yet, this aid was not constant, and Kim Ilsǒng had to maneuver between the USSR and China: North Korea's ideological disagreements with Soviet Union continued and the latter thus halted its aid, while China could not supply substantial economic aid due to the harmful consequences of the Great Leap Forward. Notwithstanding its economic predicament, China was willing to make other concessions to North Korea, including bestowing privileges in Northeast China and handing over part of Changbai/Paekdu Mountain. Hence, despite its own ideological difficulties with the USSR, North Korea maintained a somewhat neutral stand with respect to the Sino-Soviet split, albeit being a little closer to China. While it benefited from aid received from both powers this also allowed North Korea to become more independent, just as Kim Ilsǒng had hoped.

In Chapter 6 the authors reexamine the nature of Sino-North Korean relations during the first intense years of the Cultural Revolution (19661969). They emphasize that the deterioration in relations actually began before the start of the Cultural Revolution due to ideological radicalization in China and various disagreements regarding the international situation. North Korea and, particularly, Kim Ilsǒng were subject to criticism by the Red Guards; however, the CPC leaders and Mao did not express such criticism publicly. Despite the deterioration in relations and the mutual verbal attacks, both countries remained restrained and did not cut off their relations and exchanges completely. China's main concern by the late 1960s was the USSR, and it therefore devised a way of assuaging relations with the United States. In order to do this, while avoiding any risk to its relations with smaller allies such as North Korea, China first of all sought to improve its relations with North Korea.

The last chapter, Chapter 7, examines the change in China's North Ko- 
rean policy as part of its quest for rapprochement with the United States and its attempt to enhance its own status in the international community. China seems to have found a balanced solution: on the one hand, it continued to provide aid to North Korea in order to maintain their relationship but, on the other hand, it did not bend its foreign policy to North Korean considerations and thus allowed itself to initiate new foreign policies according to its own national interests. In contrast to China's expectations, North Korea did not resent China's decision to rehabilitate its relationship with the United States, possibly seeing it as serving its interests as well. Due to these new developments in China's foreign policy, this period, unlike earlier, allowed both China and North Korea to act more independently of one other in the international arena, without any special commitments or explanations. However, this period and the post-Mao period saw China's success in establishing relations with the rest of the world, while North Korea was left more reliant on China and became, to a considerable extent, an irresolvable issue or an issue that China prefers to put off dealing with for as long as possible.

The book ends with an epilogue in which the authors succinctly discuss the period of reforms and the opening-up of China under Deng Xiaoping. These reforms and changes within the Chinese political arena considerably degraded North Korea's unique focal position in China's economic exchanges and foreign relations. North Korea's strategic importance for China had begun dwindling toward the end of Mao's rule due to China's rapprochement with the United States. By Deng's period, North Korea saw itself becoming a marginal player in China's foreign relations, and their relationship gradually became more limited than before. It seems to me, however, that China and North Korea have maintained a peculiar relationship beyond just one of "give and take." What perhaps constitutes the bond and cooperative relations between China and North Korea since then is, according to the authors, China's concern and fear of a Korean unification and the North Korean political elite's reliance on China's support and aid in order to survive. In short, in spite of the North Korean leadership's occasional nuisances, such as its militant announcements, 
nuclear tests, and unconventional and hard-to-predict way of conducting affairs that bother even China, its survival serves both countries' interests, and the North Korean leadership appears to still know how to manipulate its "elder brother" or, as the authors have so aptly put it, serve as "the tail wagging the dog" (p. 242).

One of the accomplishments of this book is the disclosure of many hitherto unknown details, which allow the authors to write the history of the Sino-North Korean relations consecutively, that is, by connecting one event to another and by highlighting the motives and interests of China and North Korea. This provides a clearer picture about the relationship between China and North Korea that goes beyond the time and theme of the Korean War. By providing a comprehensive account, the authors succeed in showing the complicated and often tense relations between the two states, and are able to put forward their main argument: Sino-North Korean relations, in contrast to popular myths or official propaganda, are characterized by mutual suspicion, conflicts of interest, and ideological differences.

Whereas the book traces the development of China's policy toward North Korea, it does not state explicitly the difference between the early and later periods of Mao's rule. The authors do mention that around 1957 China's policy toward North Korea became more relaxed, and that it was aimed at guaranteeing North Korea's alignment with China in light of the evolving rivalry between China and the USSR. Therefore, China heaped vast loans and aid to North Korea, and even made significant (if not unprecedented) concessions such as handing over part of the territory of Changbai/Paekdu Mountain to North Korea, and granting it other privileges in Northeast China during the early 1960s (pp. 159-161). Yet, I think that the change of China's policy derived from Mao's realization that continuing interference in North Korean affairs would distance North Korea further and push it closer toward the USSR. It is for this reason that China's policy after 1957 changed from interference to accommodation.

The book, although well researched, suffers from certain inaccuracies, some of which derive from uncritical acceptance of earlier research. First, 
the authors relied mainly on one article addressing the issue and other archival sources from Russia and China in concluding that North Korea had never sent its forces to Manchuria during China's Civil War (p. 20). However, Guomindang intelligence reports found in Taiwan do not support the authors' argument, but rather provide valuable details about the dispatch of forces to Manchuria from North Korea. ${ }^{2}$ The difference may be due to the fact that the authors have mainly relied on diplomatic and other correspondences between Soviet or Chinese leaders, and also because many Russian and Chinese archival sources remain classified. By disregarding North Korea's direct participation in China's Civil War, the authors have magnified the disproportional mutual assistance between China and North Korea, thus emphasizing China's generosity and downplaying North Korea's role. There are several possible reasons why the authors may have done this. First, North Korea's militarization and involvement in China's Civil War, led by the USSR, was extremely clandestine. Second, for reasons of national pride and narrative, it is not improbable that the PRC has accentuated its own role in winning the Civil War over other factors including foreign involvement. The fact that North Korea was then influenced by the USSR, which orchestrated the North Korean assistance to the CPC, is also an undesirable element in China's narrative following its dispute with the USSR. It could be interesting and even important to compare China's and North Korea's own narratives regarding their wars of liberation or unification, in which both downplay the assistance provided by the other.

Second, the authors pay scant attention to Kim Muchǒng's role in challenging Kim Ilsǒng's leadership during the Korean War with the support

2 Tomer Nisimov, "The Role of North Korea in China's Civil War: The Soviet-Led North Korean Assistance to the CPC in the Northeast Theater, 1946-1948," Journal of Chinese Military History (forthcoming). It should be noted that relying on US intelligence documents, Bruce Cumings had also pointed out North Korea's dispatch of forces to Manchuria during China's Civil War, see: Bruce Cumings, The Origins of the Korean War, Vol. II: The Roaring of the Cataract, 1947-1950 (Princeton: Princeton University Press, 1990), 358-363. 
of China. Admittedly, it might be difficult to find materials on this issue, however, I believe that it deserves wider treatment, even if by simply suggesting possibilities for Kim Muchǒng's motivations and his relationship with both Peng Dehuai and Kim Ilsǒng. Marginalizing this issue allows the authors to portray China's foreign policy toward North Korea as less interventionist rather than showing its complexity and duality. Although the close relationship between Kim Muchǒng and Peng Dehuai has been overlooked by former studies and now by Shen and Xia as well, I would not rule out the possibility of Peng Dehuai's support to Kim Muchǒng during the early stages of the Korean War.

This point is relevant to the August Plenum of 1956 and the following joint Sino-Soviet delegation, which Andrei Lankov shows to be another attempt by China to remove Kim Ilsǒng from his position. While the authors have tried to refute Lankov's argument, their argument is not very convincing (p. 103). They do not agree with Lankov's notion that the joint Sino-Soviet delegation might have removed Kim Ilsǒng from the leadership but do concur that Kim had by that point become a nuisance for both the USSR and China. In his study, Lankov provides an account of a Soviet official with some insights on the joint delegation. ${ }^{3}$ The authors, on the other hand, reiterate the point that Mao did not wish to remove Kim but only to make him mend his ways. However, without providing more enlightening information about the delegation's plans or intentions, Lankov's notion remains the most probable. The fact that Peng Dehuai, who was unsympathetic toward Kim Ilsǒng, was appointed head of the Chinese delegation should be highlighted. Overall, it seems that from the time of the Korean War to the time of the joint Sino-Soviet delegation in September 1956, Peng Dehuai embodied China's genuine potential to intervene in North Korean politics. This point is downplayed by the authors but should receive more attention in future studies. Another matter, though of smaller significance, is the misidentification of Kang Kŏn as a

3 Andrei Lankov, Crisis in North Korea: The Failure of De-Stalinization (Honolulu: University of Hawai'I Press, 2005), 138. 
member of the Yan'an faction; he was, in fact, a former guerrilla in Manchuria (p. 18). ${ }^{4}$

The analysis of Sino-North Korean relations in this book suggests that China did not actively interfere in North Korean inner politics but rather tried to influence it by other "softer" means, such as providing advice, support, economic aid, and others, thus differentiating itself from the attitude of Stalin's USSR toward its "subordinate" states. While this notion is generally true, the aforementioned points somewhat weaken this analysis and the generalization of China's stance toward North Korea. If taken into consideration, these points might lead to a more balanced conception and to the conclusion that China's North Korean policy combined both strict interventional measures as well as softer and less direct approaches.

These minor shortcomings notwithstanding, the book should be lauded for its novel interpretation of Sino-North Korean relations, which highlights mutual distrust between the two states during the period of Mao's China. They elucidate China's will to maintain positive relations with North Korea for the long term, and both countries' readiness to overcome certain difficulties and reconcile with each other. In contrast to former studies that had emphasized China's interests and hegemonic stance in North Korea, the authors highlight the scope of assistance provided by China, its moderate aspects in its policies toward North Korea, and its willingness to make considerable concessions, usually in return for merely symbolic support. This book, albeit limited primarily to Mao's period, contributes also to understanding the current complex relations between China and North Korea. It forms an important basis for future studies regarding the two countries. I hope that A Misunderstood Friendship will encourage scholars to investigate the subject further and propose new perspectives and analyses, strengthening our understanding of North Korean internal politics and its role in shaping its stance toward China.

4 Daesook Suh, Kim Il Sung: The North Korean Leader (New York: Columbia University Press, 1988), 103-105. 